\title{
The influence of eutrophication and population biomass on common whitefish (Coregonus lavaretus) growth - the Lake Constance example revisited
}

\author{
Gregor Thomas and Reiner Eckmann
}

\begin{abstract}
Accelerated growth of freshwater fish during anthropogenic eutrophication has been attributed almost exclusively to the increased nutrient content, while density-dependent effects have been largely neglected. We evaluated the relative importance of these factors by studying the growth of 43 consecutive year classes of common whitefish (Coregonus lavaretus) from Upper Lake Constance. This prealpine lake underwent eutrophication from the 1950s to 1970s, followed by reoligotrophication. Because whitefish are harvested with gill nets in a strongly size-selective way, we used back-calculated lengths of average fast-growing fish to compare growth among cohorts. Standing stock biomass was estimated based upon virtual year-class strengths. Multiple linear regression analysis revealed that growth of whitefish during their second year was most strongly related to standing stock biomass followed by $\mathrm{PO}_{4}-\mathrm{P}$ content during spring turnover and by calendar year, which was incorporated as a third independent variable (adjusted $R^{2}=0.84$ ). The negative correlation between whitefish growth rate and calendar year is interpreted as evidence of an evolutionary response to the highly size-selective fishery during at least four decades. We conclude that density-dependent effects on whitefish growth are more important than had been realized previously and that the impact of eutrophication on growth of whitefish needs to be reconsidered.
\end{abstract}

Résumé : La croissance accélérée des poissons d'eau douce dans les conditions d'eutrophisation anthropique a été attribuée presque exclusivement à l'augmentation du contenu en nutriments; en revanche, les effets reliés à la densité ont été en grande partie négligés. Nous évaluons l'importance relative de ces facteurs dans une étude de la croissance de 43 classes d'âge consécutives de corégones lavarets (Coregonus lavaretus) du lac supérieur de Constance. Ce lac préalpin a subi une eutrophisation des années 1950 aux années 1970, suivie d'une ré-oligotrophisation. Parce que les corégones sont récoltés dans des filets maillants qui font une forte sélection en fonction de la taille, nous avons utilisé les longueurs obtenues par rétro-calcul de poissons moyens à croissance rapide pour comparer la croissance entre les cohortes. Nous avons estimé la biomasse du stock d'après les forces des classes d'âge virtuelles. Une analyse de régression multiple linéaire montre que la croissance des corégones durant leur seconde année est surtout reliée à la biomasse du stock, puis au contenu de $\mathrm{P}-\mathrm{PO}_{4}$ durant le brassage du printemps et à l'année du calendrier qui a été incorporée à l'analyse comme troisième variable indépendante $\left(R^{2}\right.$ ajusté $\left.=0,84\right)$. Nous interprétons la corrélation négative qui existe entre la croissance des corégones et l'année du calendrier comme une indication de la réponse évolutive à la pêche très sélective au cours d'au moins de quatre décennies. Nous concluons que les effets reliés à la densité sur la croissance des corégones sont plus importants qu'on ne le croyait antérieurement et qu'il est nécessaire d'évaluer de nouveau l'impact de l'eutrophisation sur la croissance du corégone.

[Traduit par la Rédaction]

\section{Introduction}

Understanding the effects of abiotic and biotic factors on fish growth is of both scientific and commercial interest. Among the abiotic factors, water temperature and a water body's trophic state are generally considered to be most important, while competition for food, either inter- or intraspecific, is probably the most relevant biotic factor. The trophic state of a water body and the intensity of competition for food can be modified intentionally or unintentionally by human activities over short time scales. A better understanding of human impacts on fish growth, through changes to a water body's trophic state or in competitor density, is therefore a prerequisite for the successful management of exploited fish populations.

The common whitefish (Coregonus lavaretus) is a species of great commercial importance in many prealpine lakes in central Europe (Nümann 1972; Gerdeaux 2004), as are other

Received 12 May 2006. Accepted 14 December 2006. Published on the NRC Research Press Web site at http://cjfas.nrc.ca on 16 March 2007.

J19320

G. Thomas ${ }^{1}$ and R. Eckmann. Limnological Institute, University of Konstanz, D-78457 Konstanz, Germany.

${ }^{1}$ Corresponding author (e-mail: gregor.thomas@uni-konstanz.de). 
species of the genus Coregonus in lakes, rivers, and estuaries of northern Eurasia and North America (Price et al. 2003; Hoff and Todd 2004; Salonen and Mutenia 2004). Any major changes in coregonid yields, therefore, attract the immediate attention of fishermen and managers and challenge fishery scientists to explore the likely reasons and eventually to recommend appropriate measures to stabilize yields.

The most dramatic changes in coregonid growth in central European lakes occurred during the 1960s and 1970s, when fish of consecutively younger ages were caught (Nümann 1972). Most of the studies of coregonid population dynamics claimed that anthropogenic eutrophication was the main cause of the acceleration in whitefish growth (Grimås et al. 1972; Nümann 1972). The decrease in whitefish growth from many European lakes towards the end of the 20th century was generally attributed to reoligotrophication (Kirchhofer 1995; Müller and Mbwenembo Bia 1998). Thus, it was an accepted hypothesis that changes of a lake's trophic state, through changes of primary and secondary production, was the main, if not the only, mechanism that controlled fish growth (Downing et al. 1990).

In addition to lake trophic state, however, density dependence is another key factor influencing fish growth (Walters and Post 1993; Post et al. 1999; Lorenzen and Enberg 2002). With higher population density, intraspecific competition for food can become more intense, resulting in slower individual growth. Several studies on density-dependent growth in coregonid populations have confirmed this general concept. These studies have compared whitefish growth rates among lakes with different whitefish densities (Bidgood 1973; Lehtonen and Niemelä 1998; Mayr 2001), compared growth rates before and after stock size reduction through intensive fishing (Amundsen 1988; Valkeajärvi 1992; Mills et al. 1995), or monitored whitefish stock oscillations over longer time periods (Helminen et al. 1993; Salonen et al. 1998; Viljanen et al. 2004). Most of the published studies on whitefish growth have, however, focussed either on lake trophic state or on population density.

The earlier studies on whitefish growth in European prealpine lakes were all done during the time of rapid anthropogenic eutrophication, whereby the obvious parallelism between nutrient content and whitefish growth was considered to be evidence for a monocausal relationship. As a much more extensive set of data on whitefish population dynamics, covering 43 year classes, is now available for Upper Lake Constance, we took advantage of this unique opportunity to reanalyse the earlier concepts about the influence of eutrophication on whitefish growth. The first aim of our study was to disentangle the effects of density dependence and lake trophic state on the growth of whitefish using multiple linear regression analysis.

Size-selective harvesting by a commercial fishery can change life-history traits such as size-at-age or age-atmaturity of the fish (Rijnsdorp 1993; Sinclair et al. 2002). If some of the phenotypic variation in these traits is genetic, then fishing may cause evolutionary changes in the life history (Law 2000; Conover et al. 2005). In an experimental study with Menidia menidia, size-dependent mortality did indeed select for the evolution of genotypes with growth rates that were in directions counter to the size-selective har- vest within only four generations (Conover and Munch 2002). Additionally, a gillnet fishery for lake whitefish (Coregonus clupeaformis) in Lesser Slave Lake evoked changes in growth rate, condition, and mean age, and it was suggested that the highly selective harvest of large, fast-growing fish might provoke an evolutionary response in this stock (Handford et al. 1977). As the fishery for common whitefish in Lake Constance has been highly size-selective, at least since the mid-1960s, when monofilament gill nets of a fixed mesh size replaced all formerly used fishing gears, evolutionary changes in the common whitefish stock may have occurred during the past four decades. It was, therefore, the second aim of our study to screen the available data for indications of evolutionary responses to this size-selective harvesting.

\section{Materials and methods}

\section{Study site}

Upper Lake Constance (ULC) is a large $\left(472 \mathrm{~km}^{2}\right)$, deep $\left(z_{\text {max }}=254 \mathrm{~m}, z_{\text {mean }}=101 \mathrm{~m}\right)$, warm-monomictic, prealpine lake situated at the northern fringe of the European Alps $\left(47^{\circ} 39^{\prime} \mathrm{N}, 9^{\circ} 18^{\prime} \mathrm{E}\right)$, shared by Austria, Germany, and Switzerland. The lake underwent pronounced eutrophication during the 20th century, whereby total phosphorus (P) concentrations during winter mixing in February-March $\left(\mathrm{TP}_{\text {mix }}\right)$ increased from $7 \mu \mathrm{g} \cdot \mathrm{L}^{-1}$ in 1951 to $>80 \mu \mathrm{g} \cdot \mathrm{L}^{-1}$ around 1980 (IGKB 2004). As a result of drastically reduced $\mathrm{P}$ inputs, including the banning of phosphate-containing detergents, sewage collection, and the inclusion of $\mathrm{P}$ stripping in sewage treatment, the lake had returned to oligotrophy by the beginning of the 21 st century $\left(\mathrm{TP}_{\text {mix }}\right.$ in $\left.2004=9 \mu \mathrm{g} \cdot \mathrm{L}^{-1}\right)$ (cf. Fig. 1).

Twenty-nine fish species presently occur in the lake (Eckmann and Rösch 1998), among which common whitefish is commercially the most important. An uninterrupted record of commercial catches from ULC is available since 1910. Regular surveys of the whitefish stock have been carried out monthly since the beginning of the 1960s, while less regular surveys were conducted in the 1930s, the late 1940s, and during the 1950s. These surveys showed that whitefish growth had accelerated to such a degree by the beginning of the 1960s that whitefish reached the legal minimum size (30 cm, legal gill net mesh size $38-40 \mathrm{~mm}$ ) about 2 years earlier than during the 1930s (Nümann 1972). As a consequence, an increasing fraction of the commercial yields consisted of age- 1 fish that had not yet reproduced. The obvious risk of recruitment overfishing was counteracted in 1965 by increasing the minimum mesh size to $44 \mathrm{~mm}$ and the legal minimum size to $35 \mathrm{~cm}$ (Nümann 1972).

\section{The whitefish fishery at Upper Lake Constance}

At the beginning of the 20th century, about 460 professional fishermen were licensed to fish at Lake Constance using drifting cotton gill nets and Klusgarn, a seine operated in the pelagic zone. By the mid-1960s, both gears had been replaced almost completely by more efficient monofilament nylon gill nets. During the following decades, the number of nets per licence was successively reduced from 10 to 3 , only 4 fishing days per week were allowed instead of 5, and the number of commercial fishing licences was cut by $30 \%$. 
Fig. 1. Phosphorus concentration during spring turnover (triangles) and total whitefish (Coregonus lavaretus) yield (bars) in Upper Lake Constance.

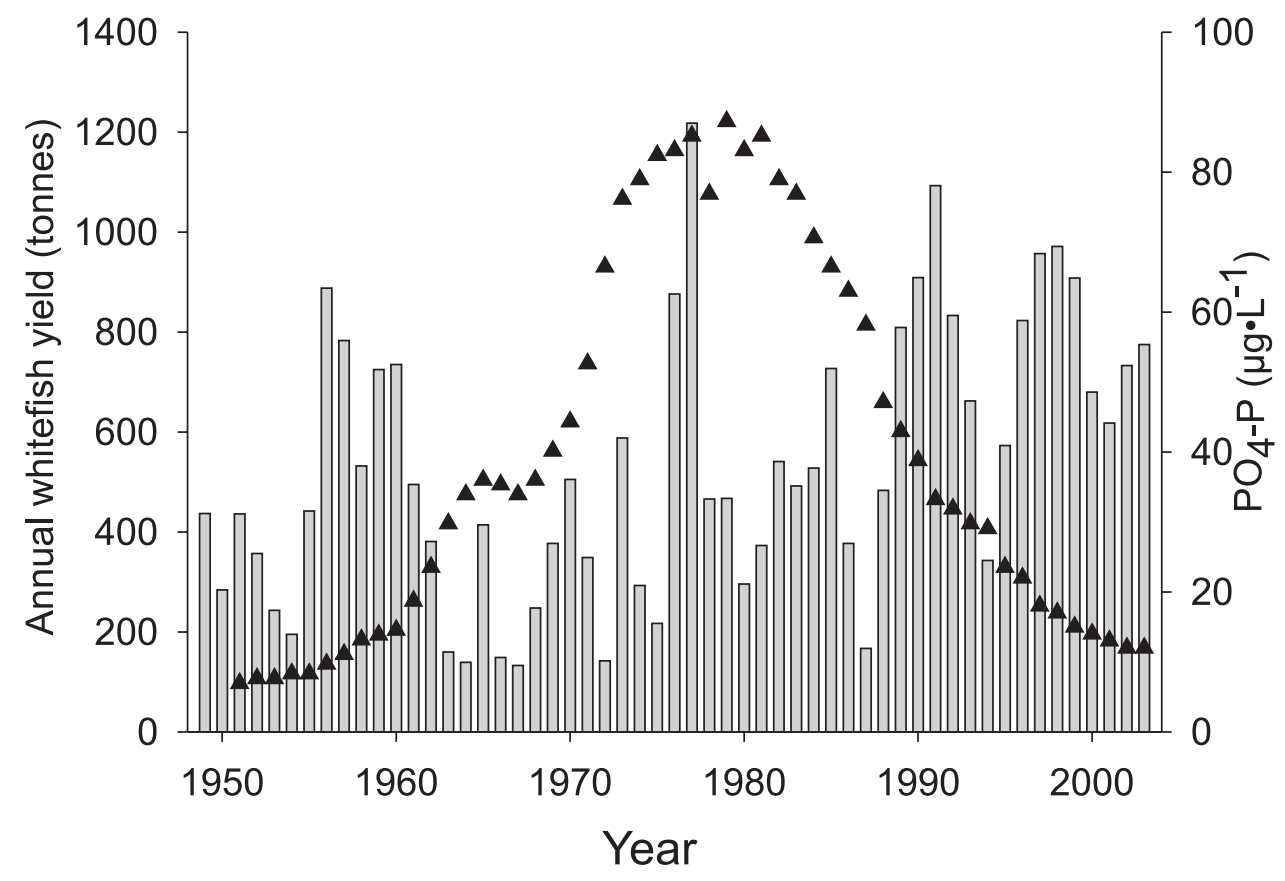

These measures were taken firstly to allow for a reasonable income to the commercial fishermen and secondly to avoid overharvesting the stock as in the 1960s and early 1970 s. Altogether, fishing intensity in 2005 had dropped to $17 \%$ of what it was in 1961 (R. Rösch, Fischereiforschungsstelle, Langenargen, Germany, personal communication).

\section{Virtual year-class strength}

Virtual year-class strength (YCS) was calculated for the annual cohorts of 1947 to 1997 . These estimates are based upon biweekly to monthly test catches using gill nets of legal mesh size. Samples are analyzed with regard to age and body weight, which provides an estimate of catch composition by age classes. Using the monthly fishermen's catch data, the number of individuals of a certain year class harvested from the lake can then be calculated month by month. Integrating all monthly harvests from year class $i$ across time yields an estimate of the virtual size of this year class (cf. Eckmann et al. 1988). To account for natural mortality, an instantaneous mortality rate of 0.2 per year was incorporated (Eckmann et al. 2002). The estimates of whitefish YCS at Lake Constance, thus, are not based on estimates of fishing mortality but on the well-documented monthly catch reports of all fishermen. These reports are made anonymous during compilation, and they are not supplied to revenue authorities to avoid bias towards low yields. Subtracting the monthly harvests from year class $i$ successively from the initial size of this cohort provides an estimate of the number of fish of year class $i$ that were present in the population in each month, from its recruitment into the fishery until the cohort was fished out. By adding up these numbers across year classes for each month, the numerical age composition of the whitefish standing stock was obtained.

\section{Size-selective harvest}

Nümann (1959) was the first to point out that whitefish are harvested in a size-selective fashion from ULC using gill nets of a legally fixed mesh size, the faster-growing fish being harvested earlier than the slower-growing members of the same cohort. In this situation, growth of fish from different year classes cannot be compared by determining size-atage, because this measure depends on the time of harvest of the fish, from which size-at-age is determined. We assessed this potential bias by back-calculating length at the end of the second year for all whitefish from the cohorts of 1991 and 1992, which had been collected with legal size (44 mm) gill nets in the regular monthly test fishery. For both year classes, size-at-age was significantly related to the year of harvest (analysis of variance, ANOVA, $F_{[2,157]}=22.09, P<$ $0.0001 ; F_{[3,210]}=35.22, P<0.0001$, for the year classes 1991 and 1992, respectively). The mean length after 2 years of whitefish sampled in their third, fourth, and fifth years of life decreased from $25.4 \mathrm{~cm}$ through 23.2 to $20.7 \mathrm{~cm}$, respectively, for the 1991 cohort and from $25.3 \mathrm{~cm}$ through 23.2 to $22.1 \mathrm{~cm}$, respectively, for the 1992 cohort. Thus, considerable bias may arise when length-at-age is determined without taking into account the age at which the fish are harvested. We therefore decided to compare growth of whitefish from different cohorts by using those fish that were harvested around the time when $50 \%$ of the total harvest from a cohort was being obtained (termed average fastgrowing fish hereafter).

\section{Back-calculation of growth}

Scales were generally sampled from the left body side between the dorsal fin and the lateral line. Three scales from each of about 50 average fast-growing fish per year class were used for growth analysis. The widths of annual growth 
increments and total scale radius were measured on each scale. Length-at-age was back-calculated according to Lee (Ricker 1968) using a $y$ intercept of $2 \mathrm{~cm}$, which had been established in a previous regression analysis of fish length on scale radius. The results from three scales were averaged, and the mean back-calculated lengths-at-age were calculated for each cohort. In total, 2347 fish were used in this growth analysis.

\section{Biomass}

The standing stock biomass of whitefish was estimated based upon the monthly numerical age-class compositions. For fish in their first and second years of life, growth in length was linearly interpolated between the initial and final lengths. The initial length for age-0 fish was set at $12 \mathrm{~mm}$, i.e., their length at hatching, while lengths after 1 and 2 years were those that had been back-calculated from the scales. The growing season of whitefish in ULC lasts from April to October. Therefore, growth was interpolated only for these months, while it was assumed to be zero in the other months. For the year classes 1947-1954, 1982-1984, and 1986-1997, length at the end of the third year could be back-calculated from scales, and the same procedure was applied for these cohorts. For fish older than 2 or 3 years, whose length-at-age could not be back-calculated from scales, von Bertalanffy growth curves were constructed. We used the available back-calculated lengths, including length at hatching $(12 \mathrm{~mm})$ and a generalized asymptotic length of $73 \mathrm{~cm}$ (www.fishbase.com) to construct Ford-Walford plots, from which the growth parameter $k$ was estimated for each cohort. From the von Bertalanffy growth model, the lengths-at-ages for fish older than 2 or 3 years were calculated. As for the younger fish, growth was linearly interpolated for the months April to October.

Length was converted into weight using separate lengthweight regressions for each decade. These were constructed from the length-weight data of around 100 fish sampled during the growing seasons in each decade. As these data covered a size range of $25-40 \mathrm{~cm}$ only, we also incorporated length-weight data for fish from 2 to $8 \mathrm{~cm}$ length, which were obtained during a standardized beach seine fishery from 1997 to 2004 (Reyjol et al. 2005). All decadal lengthweight regressions had $R^{2}$ values of 0.995 and above. For each month, the average length per age class was converted into weight, multiplied by the number of fish per age class, and then summed across age classes. Finally, to obtain an estimate of standing stock biomass for each year, we averaged monthly biomass values per year.

\section{Statistical analysis}

Multiple linear regression analysis was performed using JMP Version 4.0.4 (SAS Institute Inc., Cary, North Carolina). The length increment of the whitefish during their second year was used as the dependent variable. We considered two independent variables, $\mathrm{PO}_{4}-\mathrm{P}$ concentration during spring turnover and the natural logarithm of standing stock biomass and also incorporated the calendar year as an independent variable at a later stage in the analysis. As the standing stock biomass could be reconstructed only from
1954 onwards, i.e., when the 1947 cohort was fished out, we based our analysis on 43 years of data.

\section{Results}

YCS of the whitefish for the years 1947 to 1997 ranged between 94000 (year classes 1964 and 1965) and 4460000 (year class 1974), with a median value of 950000 individuals. In the 1950s and from the late 1980s until present, the standing stock comprised five to six age classes, and biomass ranged from 500 tonnes $\left(9.3 \mathrm{~kg} \cdot \mathrm{ha}^{-1}\right)$ to 2000 tonnes (37.3 kg.ha ${ }^{-1}$ ) (Fig. 2). During the 1960s and early 1970s, biomass never exceeded 500 tonnes and even fell below 30 tonnes in the spring of 1967. This stock comprised only young fish up to 3 years of age. Exceptionally strong year classes dominated the standing stock biomass during 23 years, most notably the year classes of 1974 and 1982 . Biomass increased steadily from the early 1980s, except for the years 1986-1987 and 1992-1994. During the 1990s, standing stock biomass reached the highest values on record, being about twice as high as in the 1950s. Age classes 3 and 4 dominated the stock during the most recent years.

Length of whitefish after their first year did not vary much, i.e., by a factor of 1.5, during the study period (Fig. 3), but by contrast, length increment during the second year differed by a factor of 1.9. The fish grew nearly $10 \mathrm{~cm}$ more during their second year in the 1970s when compared with the 1950s and 1990s. Although the length after 3 years could not be back-calculated from scales for the entire study period, it showed a similar trend.

Linear regression analysis revealed that length after the first year was only weakly correlated with standing stock biomass $\left(R^{2}=0.24, P=0.0008, n=43\right)$, and no correlation existed with $\mathrm{PO}_{4}-\mathrm{P}$ concentration $\left(R^{2}=0.06, P=0.103\right)$ or calendar year $\left(R^{2}=0.005, P=0.609\right)$. The length increments of the whitefish during their second year, however, were significantly correlated with the natural logarithm of standing stock biomass (tonnes) $(P<0.0001)$ and with the $\mathrm{PO}_{4}-\mathrm{P}$ concentration $\left(\mu \mathrm{g} \cdot \mathrm{L}^{-1}\right)$ during spring mixing $(P<$ 0.0001 ), with an adjusted $R^{2}$ value of 0.78 (Table 1 ). The year 1954, the first year in our analysis, was excluded because it was considered to be an outlier. When the calendar year was included as the third independent variable, the model fit improved (adjusted $R^{2}=0.84$ ). The first two independent variables were still significant at $P<0.0001$, and the variable calendar year was significant at $P<0.0004$ with a negative influence on length increment during the second year (Table 1). In both models, the residuals were normally distributed and not autocorrelated.

To assess the relative importance of the three independent variables, scaled estimates centred by their means were used. These estimates indicate how much the length increment during the second year changes when one variable ranges from its lowest to its highest value while the other two variables are set to their mean value. Length increment changes due to standing stock biomass (range: 52.9-1976 tonnes) are $6.0 \mathrm{~cm}$; they are $3.5 \mathrm{~cm}$ due to $\mathrm{PO}_{4}-\mathrm{P}$ concentration (range: 8.3-87.2 $\mu \mathrm{g} \cdot \mathrm{L}^{-1}$ ) and $2.6 \mathrm{~cm}$ due to the variable calendar year (range 1955-1997). This analysis indicates that standing stock biomass had the strongest influence on the growth 
Fig. 2. Standing stock biomass by age classes of whitefish (Coregonus lavaretus) in Upper Lake Constance based upon virtual yearclass strengths.

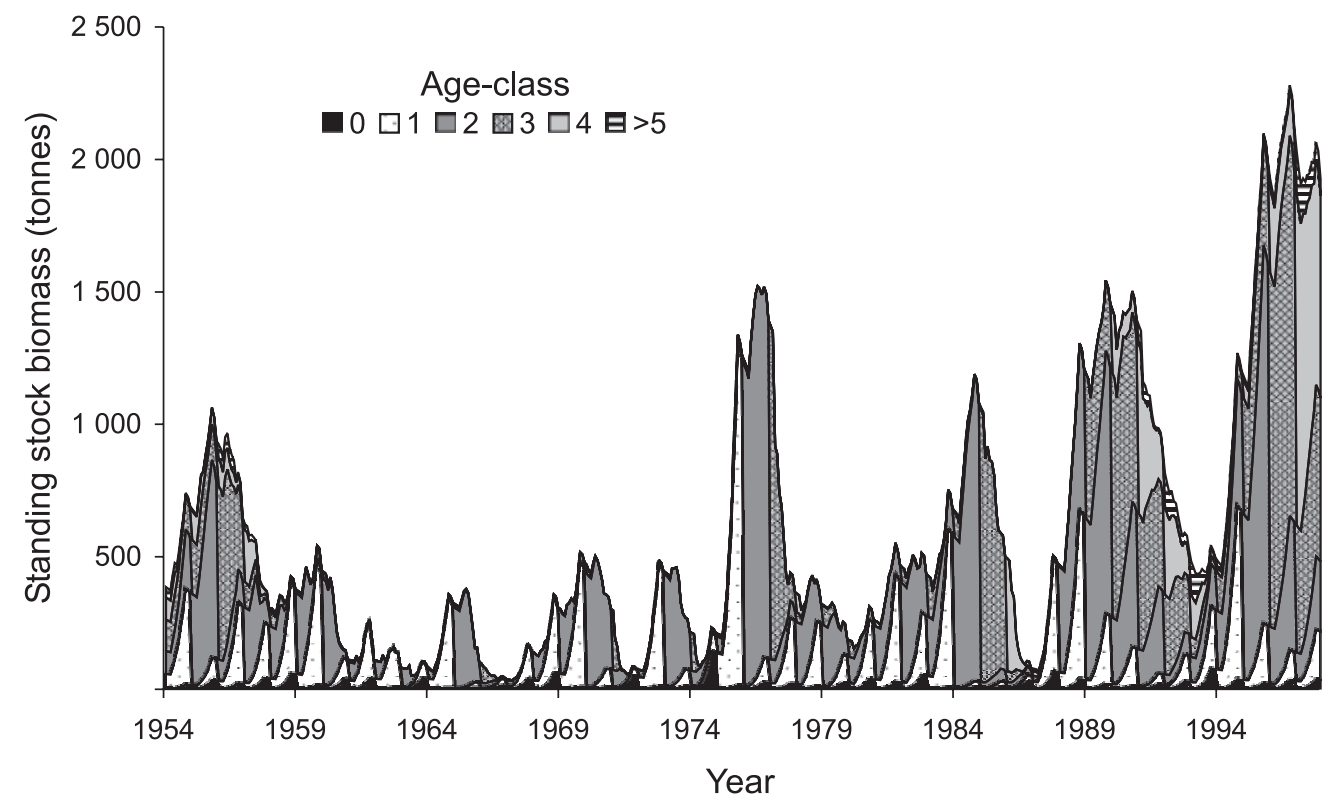

Fig. 3. Back-calculated lengths for the 1947-1997 cohorts of whitefish (Coregonus lavaretus) from Upper Lake Constance at the end of their first (solid triangles), second (shaded triangles), and third (open triangles) year of life. Second-degree polynomials were fit to the data to show trends.

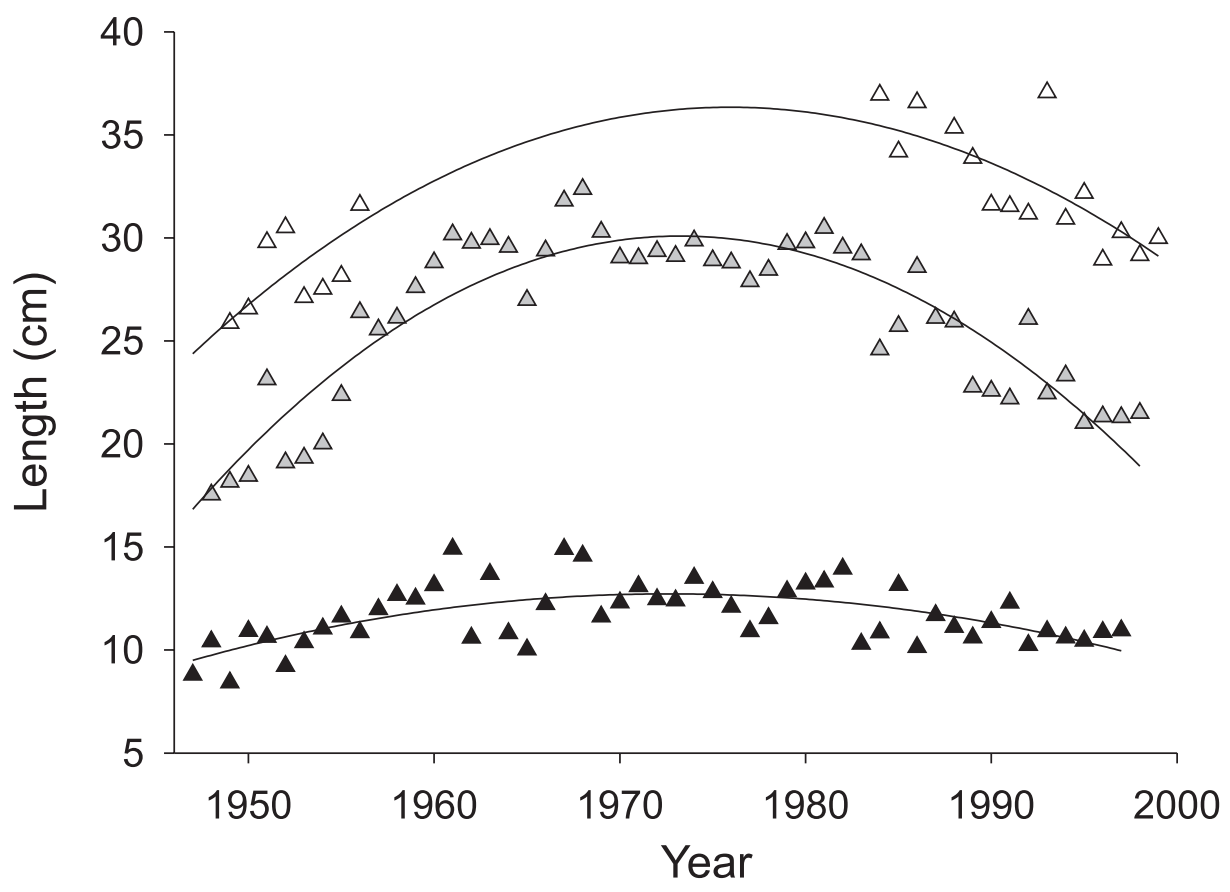

of whitefish during their second year, followed by $\mathrm{PO}_{4}-\mathrm{P}$ concentration and the variable calendar year.

\section{Discussion}

Our results support and at the same time extend the earlier concept about the influence of eutrophication on the growth of whitefish. The earlier studies focussed exclusively on lake nutrient content and considered increasing lake P loads and their bottom-up effects on the pelagic food chain to be the ultimate and only cause of faster fish growth (Downing et al. 1990). Growth deceleration towards the end of the 20th century was attributed exclusively to lake reoligotrophication (Kirchhofer 1995; Eckmann and Rösch 1998; Müller and Mbwenembo Bia 1998). The similar time course of $\mathrm{P}$ concentration and whitefish growth, e.g., in ULC (Fig. 4), lends 
Table 1. Results of two- and three-factor multiple regression analyses of whitefish (Coregonus lavaretus) growth in Upper Lake Constance from 1955 to 1997.

\begin{tabular}{llllll}
\hline & \multicolumn{2}{l}{ Model 1} & & \multicolumn{2}{c}{ Model 2 } \\
\cline { 2 - 3 } Term & Estimate & $P$ & & Estimate & $P$ \\
\hline Intercept & 26.596 & $<0.0001$ & & 143.223 & $<0.0001$ \\
ln biomass & -2.150 & $<0.0001$ & & -1.668 & $<0.0001$ \\
PO $_{4}-\mathrm{P}$ & 0.034 & $<0.0001$ & & 0.044 & $<0.0001$ \\
Calendar year & - & - & -0.061 & $<0.0004$ \\
Adjusted $R^{2}$ & 0.78 & & & 0.84 & \\
\hline
\end{tabular}

Note: Length increment in the second year is the dependent variable. The natural logarithm of standing stock biomass (ln biomass), $\mathrm{PO}_{4}-\mathrm{P}$ concentration during spring mixing, and calendar year were used as independent variables.

Fig. 4. Length increment of whitefish (Coregonus lavaretus) in their second year (open triangles), phosphorus concentration (open squares), and yearly averages of standing stock biomass of lake whitefish (solid diamonds) in Upper Lake Constance.

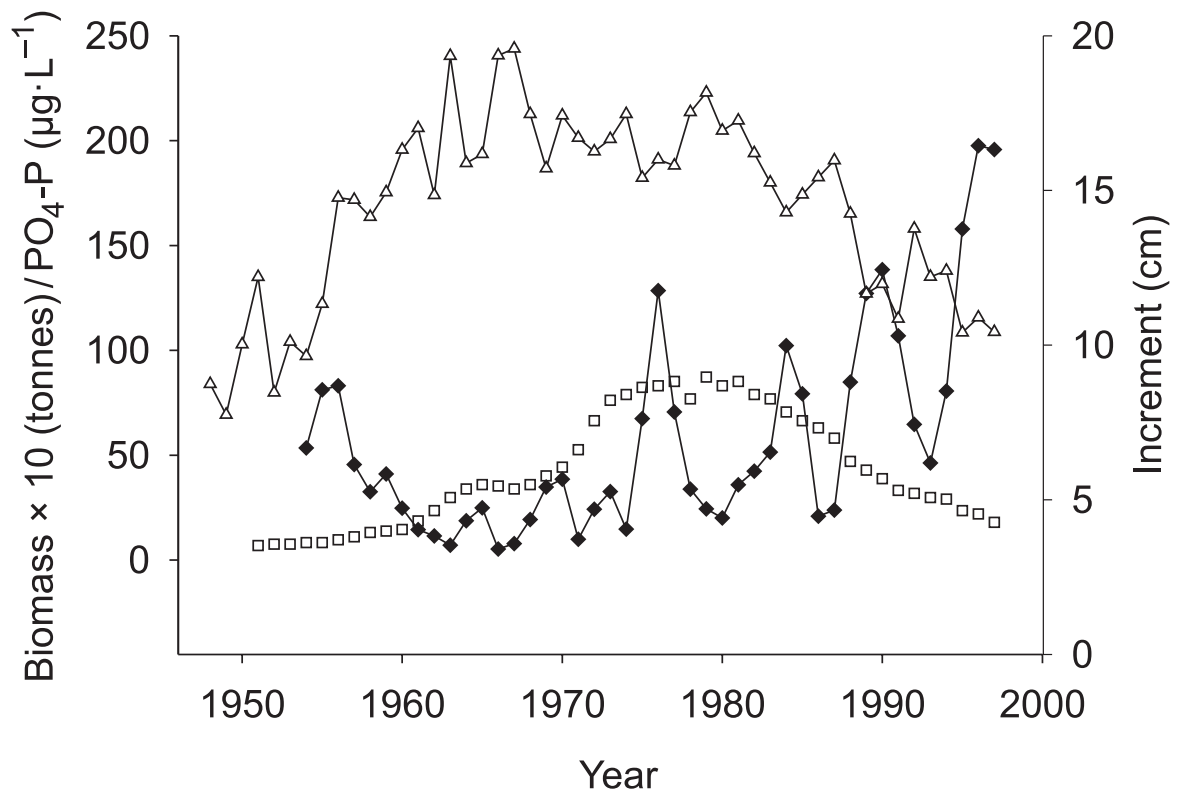

supports to this general concept. Our analysis, by contrast, demonstrates that standing stock biomass has an even stronger effect on whitefish growth.

Standing stock biomass of whitefish showed an opposite trend as compared with $\mathrm{P}$ concentration during the study period, decreasing to consistently low levels in the 1960s and early 1970s and increasing towards the 1990s, suggesting an influence of stock biomass on whitefish growth in parallel to that of eutrophication. The evolution of standing stock biomass over time was, however, more irregular than the regular increase and then decrease of $\mathrm{P}$ concentration. Particularly weak or strong year classes resulted in low or high levels of whitefish biomass, respectively, which were observed at similar levels of $\mathrm{P}$ concentration. This allowed disentangling the effects of both factors on whitefish growth using data from 43 consecutive years. The decrease in the standing stock biomass of whitefish during the late 1950s to early 1960s was most likely caused by greater fishing intensity because of the increased use of efficient nylon gill nets. The subsequent increase in the standing stock biomass of whitefish can be attributed in part to the global reduction of fishing intensity down to $17 \%$ from 1961 to 2005 and to the slower growth of whitefish, which results in higher age-atcapture.

Lake trophic state is supposed to influence whitefish growth because of bottom-up enhancement of secondary production. The yearly average crustacean zooplankton density in ULC, integrated over the entire water column, increased from $4 \times 10^{5}$ individuals $\cdot \mathrm{m}^{-2}$ to above $10^{6}$ during the 1960s and 1970s and has dropped back in recent years to values between 4 and $6 \times 10^{5}$ individuals $\cdot \mathrm{m}^{-2}$ (IGKB 2004). Whitefish stock biomass, on the other hand, most probably affects growth because of intraspecific competition for food, because lake whitefish are by far the dominant consumers of zooplankton in ULC. Potential heterospecific competitors are either not very abundant (brown trout (Salmo trutta)) or they use the pelagic zone only sporadically (Eurasian perch (Perca fluviatilis)). Intraspecific competition for food is, therefore, much more crucial than interspecific competition.

Density-dependent growth of fish, mediated through intraspecific resource competition, can be an important controlling factor of fish population dynamics (Wanzenböck et al. 
2002). Food limitation is of course a prerequisite for density-dependent effects on growth. A comparison between whitefish and zooplankton biomasses in ULC during the past decades highlights the potential for intraspecific competition for food in this lake. During the year 1989, an average whitefish standing stock of 1270 tonnes consumed roughly 13000 tons of zooplankton during the growing season (Eckmann et al. 2002). When we assume a similar consumption of zooplankton for the entire study period, the demand for zooplankton would range from 730 to 20200 tonnes, i.e., more than a 27 -fold difference. The yearly average crustacean zooplankton density in ULC, however, ranged from $4 \times$ $10^{5}$ to $1.4 \times 10^{6}$ individuals $\cdot \mathrm{m}^{-2}$ (IGKB 2004), i.e., only a 3.5-fold difference.

The influence of both $\mathrm{P}$ concentration and standing stock biomass on whitefish growth is much less pronounced in the first year than in the second year of their life. This can be attributed to the different temperatures experienced and to the different food sources utilized by young-of-the-year and older whitefish. During their first months of life, whitefish live in the epilimnion, where their growth is mainly controlled by temperature rather than zooplankton concentration (Eckmann and Pusch 1989). Only later in summer do young whitefish avoid the warm epilimnion and move to deeper layers, where they eventually join their older conspecifics. Nevertheless, they utilize different food resources, preying mainly on daphnids, whereas larger whitefish select large carnivorous crustaceans, such as Bythotrephes longimanus and Leptodora kindtii in addition to daphnids (Eckmann et al. 2002). Juvenile and adult whitefish stay within or slightly below the thermocline during the growing season (Ptak and Appenzeller 1998) at temperatures below $14{ }^{\circ} \mathrm{C}$. Their growth, therefore, depends much less on temperature when compared with the very young whitefish, and the influence of food concentration, which depends on lake trophic state and competitor biomass, on their growth is more pronounced.

Including the calendar year as the third independent variable in the regression model improved the model fit, suggesting that whitefish growth rate declined with time, independent of lake trophic state and intensity of competition. The scaled estimate for the variable calendar year suggests that growth of 2-year-old fish declined by almost $0.6 \mathrm{~cm}$ every 10 years. We consider this result to be circumstantial evidence that the highly size-selective fishery during at least four decades provoked an evolutionary response in the stock by selecting for genotypes with lower growth potential. A similar conclusion was reached by (Handford et al. 1977), who studied growth rates, condition, and mean ages of a lake whitefish stock over 34 years.

The potential for an evolutionary change in the growth rate of ULC whitefish is supported by the differences in growth rates of fish from the 1991 and 1992 cohorts, which were harvested from the lake in consecutive years. The selection differential, in this case the difference in length after two growing seasons between the fish harvested at the end of their second year and the population mean, was $1.7 \mathrm{~cm}$ for the 1991 cohort and $1.6 \mathrm{~cm}$ for the 1992 cohort. Assuming a heritability of 0.2 , which is typical for life-history traits (Conover and Munch 2002), these data demonstrate the potential for an evolutionary response to size-selective har- vest. This estimate of the selection differential is, however, conservative, because it is based upon cohorts that were fished out during 68 and 71 months, respectively. During the 1960s and early 1970s, whitefish grew so fast that cohorts were fished out over 17-44 months. Up to $60 \%$ of these cohorts were even fished at age $1+$, i.e., before the fish had reproduced, whereby the fastest-growing fish were effectively excluded from contributing genes to the next generation.

We decided to compare growth between cohorts by using the length after 2 years of the average fast-growing fish, because we have shown that whitefish are harvested in a highly size-selective way from ULC. The definition of the point in time when $50 \%$ of a cohort was fished out was possible with high accuracy, based upon monthly catch records and on the monthly age composition of catches derived from the test fishery. As whitefish yields are not evenly distributed across months within a fishing year, this approach is more accurate compared with traditional virtual population analysis using a constant instantaneous rate of fishing mortality. In the case of natural mortality, however, we have incorporated a constant instantaneous rate of 0.2 per year. Without considering natural mortality, the biomass of those cohorts that were fished out over a longer time (in some cases more than 5 years) would have been systematically underestimated as compared with cohorts fished out more quickly (during less than 2 years).

The highly significant influence of stock biomass on whitefish growth needs to be carefully considered in the future management of the whitefish fishery in ULC and elsewhere. An earlier analysis of the factors that influence whitefish year-class strength in ULC has demonstrated that stronger year classes are produced when lake surface temperature increases earlier in spring (Eckmann et al. 1988). This hypothesis has recently been supported by a reanalysis of an extended data set covering 52 years (Straile et al. 2007). Based upon the earlier analysis, Trippel et al. (1991) have predicted that whitefish year-class strength will likely increase as a result of global climate change. This would probably result in larger stock size, which might translate into enhanced intraspecific competition for food and ultimately into a further reduction of growth rate. Under this scenario, the present stocking practice will need reconsideration. The high standing stock biomass of whitefish in Lake Geneva, for example, is attributed among other factors to an intensive stocking program (Gerdeaux 2004). Even if the precise contribution of stocking to the whitefish population size in ULC were unknown so far, any reduction of stock biomass would contribute to alleviating intraspecific competition for food. This might be even more necessary in the future, as $\mathrm{P}$ concentrations in ULC are continuing to decrease and a further reduction of zooplankton biomass can be expected.

The present results apply not only to ULC but probably to many other coregonid lakes in Europe and elsewhere. Anthropogenic eutrophication was a worldwide problem during the second half of the 20th century, and it affected many lakes dominated by coregonids (Christie 1972; Colby et al. 1972; Grimås et al. 1972). In many of these lakes, eutrophication has been successfully abated in the meantime, and the lakes have returned or are returning to preeutrophication levels (Eckmann et al. 2007). Additionally, 
fishing intensity has probably changed in many of these lakes in a way similar to that in ULC, as monofilament gill nets became widely used during the 1950s and early 1960s. It can therefore be speculated that stock size might have decreased in parallel to eutrophication in several other lakes as well, so that the former concepts about the sole dependence of whitefish growth on nutrient concentration deserve to be reconsidered.

\section{Acknowledgements}

We sincerely thank M. Kugler (Amt für Jagd und Fischerei, St. Gallen, Switzerland) for providing catch statistics, H. Loeffler and B. Engesser (Institute for Lake Research, Langenargen) and R. Roesch and H.P. Billmann (Fischereiforschungsstelle, Langenargen) for providing catch statistics, data from the regular test fishery, and whitefish scales for analysis. We are grateful to Nina Ebert, Felix Heindl, Barbara Schlick, and Daniel Sievers for their assistance in data input and scale analyses. M. Morris corrected the English. This project was supported within the priority program AQUASHIFT by the Deutsche Forschungsgemeinschaft (EC 146/3-1).

\section{References}

Amundsen, P.-A. 1988. Effects of an intensive fishing programme on age structure, growth and parasite infection of stunted whitefish (Coregonus lavaretus L. s.l.) in Lake Stuorajarvi, northern Norway. Finn. Fish. Res. 9: 425-434.

Bidgood, B.F. 1973. Divergent growth in two lake whitefish (Coregonus clupeaformis) populations. J. Fish. Res. Board Can. 30: 1683-1696.

Christie, W.J. 1972. Lake Ontario: effects of exploitation, introductions and eutrophication on the salmonid community. J. Fish. Res. Board Can. 29(6): 913-929.

Colby, P.J., Spangler, G.R., Hurley, D.A., and McCombie, A.M. 1972. Effects of eutrophication on salmonid communities in oligotrophic lakes. J. Fish. Res. Board Can. 29(6): 975-983.

Conover, D.O., and Munch, S.B. 2002. Sustaining fisheries yields over evolutionary time scales. Science (Washington, D.C.), 297: 94-96.

Conover, D.O., Arnott, S.A., Walsh, M.R., and Munch, S.B. 2005. Darwinian fishery science: lessons from the Atlantic silverside (Menidia menidia). Can. J. Fish. Aquat. Sci. 62: 730-737.

Downing, J.A., Plante, C., and Lalonde, S. 1990. Fish production correlated with primary productivity, not the morphoedaphic index. Can. J. Fish. Aquat. Sci. 47: 1929-1936.

Eckmann, R., and Pusch, M. 1989. The influence of temperature on growth of young coregonids (Coregonus laveretus L.) in a large prealpine lake. Rapp. P.-V. Réun. Cons. Int. Explor. Mer, 191: 201-208.

Eckmann, R., and Rösch, R. 1998. Lake Constance fisheries and fish ecology. Arch. Hydrobiol. Spec. Issues Adv. Limnol. 53: 285-301.

Eckmann, R., Gaedke, U., and Wetzlar, J. 1988. Effects of climatic and density-dependent factors on year-class strength of Coregonus laveretus in Lake Constance. Can. J. Fish. Aquat. Sci. 45(6): 1088-1093.

Eckmann, R., Becker, M., and Schmid, M. 2002. Estimating food consumption by a heavily fished stock of zooplanktivorous Coregonus lavaretus. Trans. Am. Fish. Soc. 131: 946-955.
Eckmann, R., Gerdeaux, D., Müller, R., and Rösch, R. 2007. Reoligotrophication and whitefish fisheries management - a workshop summary. Arch. Hydrobiol. Spec. Issues Adv. Limnol. 60: $351-358$.

Gerdeaux, D. 2004. The recent restoration of whitefish fisheries in Lake Geneva: the role of stocking, reoligotrophication, and climate change. Ann. Zool. Fenn. 41: 181-189.

Grimås, U., Milsson, N.-A., and Wendt, C. 1972. Lake Vättern: effects of expoitation, eutrophication, and introduction on the salmonid community. J. Fish. Res. Board Can. 29(6): 807-817.

Handford, P., Bell, G., and Reimchen, T. 1977. A gillnet fishery considered as an experiment in artificial selection. J. Fish. Res. Board Can. 34: 954-961.

Helminen, H., Auvinen, H., Hirvonen, A., Sarvala, J., and Toivonen, J. 1993. Year-class fluctuations of vendace (Coregonus albula) in Lake Pyhäjärvi, southwest Finland, during 1971-90. Can. J. Fish. Aquat. Sci. 50: 925-931.

Hoff, M.H., and Todd, T.N. 2004. Status of the shortjaw cisco (Coregonus zenithicus) in Lake Superior. Ann. Zool. Fenn. 41(1): 147-154.

IGKB. 2004. Limnologischer Zustand des Bodensees 31. Available from the Internationale Gewässerschutzkommission für den Bodensee (IGKB). 2. Auflage. Bregenz, Austria. ISBN 3902290-04-8. pp. 31-39.

Kirchhofer, A. 1995. Growth characteristics of coregonid populations in three lakes with different trophic states and decreasing nutrient concentrations. Arch. Hydrobiol. Spec. Issues Adv. Limnol. 46: 61-70.

Law, R. 2000. Fishing, selection, and phenotypic evolution. ICES J. Mar. Sci. 57: 659-668.

Lehtonen, H., and Niemelä, E. 1998. Growth and population structure of whitefish (Coregonus lavaretus (L.)) in mountain lakes of northern Finland. Arch. Hydrobiol. Spec. Issues Adv. Limnol. 50: $81-95$.

Lorenzen, K., and Enberg, K. 2002. Density-dependent growth as a key mechanism in the regulation of fish populations: evidence from among-population comparisons. Proc. R. Soc. Lond. B Biol. Sci. 269: 49-54.

Mayr, C. 2001. The influence of population density on growth of whitefish (Coregonus lavaretus L.) in four prealpine lakes. Limologica, 31: 53-60.

Mills, K.H., Chalanchuk, S.M., Allan, D.J., and Mohr, L.C. 1995. Responses of lake whitefish (Coregonus clupeaformis) to exploitation at the Experimental Lakes Area, northwestern Ontario. Arch. Hydrobiol. Spec. Issues Adv. Limnol. 46: 361-368.

Müller, R., and Mbwenembo Bia, M. 1998. Adaptive management of whitefish stocks in lakes undergoing re-oligotrophication: the Lake Lucern example. Arch. Hydrobiol. Spec. Issues Adv. Limnol. 50: 391-399.

Nümann, W. 1959. Das Wachstum der Blaufelchen und seine Berechnung bei Erfassung aller Individuen der einzelnen Jahrgänge in Abhängigkeit von der Stärke des Jahrgangs, den jährlich variierenden Aussenfaktoren, der Eutrophierung und den regionalen Unterschieden des Sees. Archiv. Fischwiss. 10: $5-20$.

Nümann, W. 1972. The Bodensee: effects of expoitation and eutrophication on the salmonid community. J. Fish. Res. Board Can. 29(6): 833-847.

Post, J.R., Parkinson, E.A., and Johnston, N.T. 1999. Densitydependent processes in structured fish populations: interaction strengths in whole-lake experiments. Ecol. Monogr. 69: 155-175.

Price, H., Pothoven, S.A., McCormick, M.J., Jensen, P.C., and Fahnenstiel, G.L. 2003. Temperature influence on commercial 
lake whitefish harvest in Eastern Lake Michigan. J. Gt. Lakes. Res. 29(2): 296-300.

Ptak, J.K., and Appenzeller, A.R. 1998. Size, depth, and frequency of pelagic Lake Constance whitefish (Coregonus lavaretus L.) shoals during the seasons: a hydroacoustic study. Arch. Hydrobiol. Spec. Issues Adv. Limnol. 50: 237-248.

Reyjol, Y., Fischer, P., Lek, S., Rösch, R., and Eckmann, R. 2005. Studying the spatiotemporal variation of the littoral fish community in a large prealpine lake, using self-organizing mapping. Can. J. Fish. Aquat. Sci. 62: 2294-2302.

Ricker, W.E. 1968. Methods for assessment of fish production in fresh-waters. Blackwell Scientific Publications, Oxford and Edinburgh.

Rijnsdorp, A.D. 1993. Fisheries as a large-scale experiment on life-history evolution: disentangling phenotypic and genetic effects in changes in maturation and reproduction of North Sea plaice, Pleuronectes platessa L. Oecologia, 96(3): 391-401.

Salonen, E., and Mutenia, A. 2004. The commercial coregonid fishery in northernmost Finland - a review. Ann. Zool. Fenn. 41(1): 351-355.

Salonen, E., Ahonen, M., and Mutenia, A. 1998. Development of whitefish (Coregonus lavaretus) population and effects of largescale compensation stocking in Lake Inari northern Finland. Arch. Hydrobiol. Spec. Issues Adv. Limnol. 50: 439-448.

Sinclair, A.F., Swain, D.P., and Hanson, J.M. 2002. Measuring changes in the direction and magnitude of size-selective mortal- ity in a commercial fish population. Can. J. Fish. Aquat. Sci. 59: 361-371.

Straile, D., Eckmann, R., Jüngling, T., Thomas, G., and Löffler, H. 2007. Influence of climate variability on whitefish (Coregonus lavaretus) year-class strength in a deep, warm monomictic lake. Oecologia, 151: 521-529.

Trippel, E.A., Eckmann, R., and Hartmann, J. 1991. Potential effects of global warming on whitefish in Lake Constance, Germany. Ambio, 20(6): 226-231.

Valkeajärvi, P. 1992. Effects of increased fishing effort on the european whitefish (Coregonus wartmanni) stock in Lake Päijänne. Pols. Arch. Hydrobiol. 39: 817-825.

Viljanen, M., Turunen, T., and Väisänen, P. 2004. Fluctuations in year-class strength of the vendace (Coregonus albula $(\mathrm{L}$.$) ) in the$ small, mesohumic, oligotrophic Suomunjärvi, a lake in eastern Finland. Ann. Zool. Fenn. 41: 241-248.

Walters, C.J., and Post, J.R. 1993. Density-dependent growth and competitive asymmetries in size-structured fish populations: a theoretical model and recommendations for field experiments. Trans. Am. Fish. Soc. 122: 34-45.

Wanzenböck, J., Gassner, H., Hassan, Y., Lahnsteiner, B., and Hauseder, G. 2002. Ecology of European whitefish, Coregonus lavaretus, in two Austrian lakes in relation to fisheries management and lake productivity. In Management and ecology of lake and reservoir fisheries. Edited by I.G. Cowx. Blackwell Science, Oxford. pp. 58-69. 